\title{
A Future of Hope: Artists in a Context of Insecurity
}

\author{
Ludovic Ouhonyioué Kibora
}

Introduction

After dark centuries of slavery and colonization, the socio-political conditions under which the countries of the African continent acquired their political independence have made it exceedingly difficult to kickstart any real development dynamic. For a long time between the wars, famines and various epidemics that have been ravaging it, the continent's prospects have been accompanied by a steady beat of 'Afro-pessimism', and current conditions in the Sahel region are not about to change that. Indeed, the deterioration of the security situation in the West African Sahel (particularly in Burkina Faso, Mali, and Niger) is worrying. In fact, in Burkina Faso this deterioration has accelerated so much since 2018, that many Western governments have increased the number of red and orange zones on the country's map to which their nationals are not allowed to travel. Despite this situation, however, another future is possible, for Burkina Faso and for the entire African continent (see Mbembé 2010, 2020; Sarr 2016).

Despite its economic poverty, Burkina Faso is an important cultural crossroads and its popular cultural events attract many foreign tourists. ${ }^{1}$ Growing insecurity, however, has instigated a kind of psychosis and has exacerbated the despair many Burkinabè feel about the country's socio-economic prospects. Yet, in stark contrast to the usual Afro-pessimism, its artists emphasize a need to resist and paint a much brighter African future, a vision that many youngsters share via their social networks. The strong and sustained mobilizations resulting from this optimism were contributory factors in the socio-political transformations that took place in Burkina Faso at the end of October 2014 (Hagberg 2017).

This chapter is based on my empirical research with two artistic initiatives. The first, the Récréâtrales, is a festival staged in Ouagadougou on a biannual basis, the eleventh of which was held in $202 \mathrm{O}$. The second took me to the studio of Abou Sidibé, a Burkinabè sculptor whose work was shown at the Future

1 Ouagadougou's Pan-African Festival of Cinema and Television and its International Craft Fair have been regular occurrences in Burkina Faso's capital since the 1970s and 1980s respectively.

(C) LUDOVIC OUHONYIOUÉ KIBORA, 2022 | DOI:10.1163/9789004471641_025 
Africa Visions in Time (FAVT) exhibition. ${ }^{2}$ With them, and through our shared experiences of collaborating as artists and researchers, I analyse the future as one of hope. How can artists act as mouthpieces of the communities of which they are part? How can they, in the footsteps of many intellectuals, heed Joseph Ki-Zerbo's (2004) cry of For when Africa?

This, and the lived experiences of these artists, is the vantage point from which I want to look into this African future, but not without first sketching a brief outline of the research framework.

\section{Burkina Faso: from Hoping for Socio-Political Reforms to Multiple Insecurities}

Since gaining its political independence, the socio-political life of Burkina Faso has been both dynamic and hectic (Hagberg et al. 2017). As far back as January 1966, workers and their unions mobilizing against the austerity measures imposed on them were able to depose the country's first president, Maurice Yaméogo. Then, in 2014, the people again took to the streets - over which the paltry showing of security forces were unable to maintain control - to oust President Blaise Compaoré, who had occupied the highest office since 1987 (Chouli 2015; Frère and Englebert 2015; Hagberg 2015; Kibora et al. 2017). On 30 and 31 October 2014, almost twenty-seven years to the day since Compaoré had risen to power, a strong coalition of workers, civil society organizations and ordinary citizens initiated a series of socio-political reforms (Hagberg et al. 2017). It is worth remembering that Blaise Compaoré assumed power after President Thomas Sankara's assassination in a bloody coup d'etat. Despite his short period in power (1983-87), Sankara's charisma, actions and speeches led the Burkinabè revolution and united the African youth (Jaffré 1997; Martens and Meesters 1989; Sennen 1989; Somé 1990). This positive image helped to mobilize many Burkinabè youngsters, for whom the fall of the Compaoré regime provided the perfect opportunity to continue Sankara's unfinished work.

After a year of political transition (during which 'popular resistance' thwarted an attempted coup) the citizens of Burkina Faso resolutely directed the country towards a new horizon. During these tense moments in the

2 FAVT was an exhibition held from 27 October-3 November 2018 at the National Museum in Ouagadougou and organized by the Goethe Institute of Ouagadougou, in collaboration with the Academy of Advanced African Studies, Iwalewahaus, University of Bayreuth. 
country's history everybody knew that nothing would ever be the same again, or, as they put it, plus rien ne sera comme avant.

The wish to launch a new democratic experiment in the country was real, and the first democratic elections after the popular insurrection installed Roch Marc Christian Kaboré as the new president. At the same time, however, the country entered a period of insecurity (Hagberg et al. 2019; Kibora 2019; Kibora et al. 2018). For a long time, many Burkinabè had considered terrorism a distant prospect, and one not to be confounded with old territorial claims (as in Mali and Niger). In 2015, however, unidentified armed men launched attacks first in the west and later in the north of the country. ${ }^{3}$ Since then, insecurity has mounted to the point of affecting all sectors of the country's socioeconomic life.

This resurgence of terrorist violence and insecurity undoubtedly destabilizes the inhabitants of the Sahel, and has profound physical, psychological, social, political and economic effects. It is, however, in this context that artists, through their actions, insist on a positive vision of the future, beyond insecurities. Burkina Faso (or its neighbours Mali and Niger) are of course not isolated cases: many countries on the African continent had to go through hardship before finding themselves on the road to an African renaissance (DoNascimento 2008). Many years ago, the eminent scholar Cheikh Anta Diop $(1954,1996)$ advocated that the key to an African renaissance lay in its culture. This also is the vision of the Burkinabè artists who feature in the remainder of this chapter.

\section{Artists Show us an African Future}

In Burkina Faso, four professional theatre companies joined forces to pursue their artistic projects under the telling banner of Fédération du Cartel (federation of the Cartel). The idea was to set up an administrative structure to manage the common vision of a theatre that does more than just entertain, it is also instrumental in raising consciousness and pointing out new venues (and ethics) of possibility (Appadurai 2013). This initiative brought together Théatr' Éclair (under the direction of Alain Héma), Théatr' Évasion (Ildevert Méma), Falinga (Étienne Minoungou) and Grâce Théatre (Anatole Kouama) (Kibora and Bationo 2010). Together they launched a common project called Récréâtrales (or, to be more explicit, pan-African residences of creative writing,

3 Hitherto, very few of the hundreds of terrorist acts committed so far have been claimed. 
training and dissemination in theatre), which made its debut in 2002. It had gained from previous experiences by Étienne Minoungou and Alexis Guingané as part of the Théâtre de la Fraternité (Theatre of Brotherhood). Jean-Pierre Guingané had started this theatre company in 1998 with a view to producing theatrical performances built on conviviality, to question the problems Africa was experiencing and to find traces of hope. ${ }^{4}$ Hence, the emphasis lay on improvisation, as when a dream does not order you what to do, but suggests a better tomorrow. A second edition in 2003 also included the Burkinabè actor and playwright Alain Héma and sought to 'Africanize' the experiment of the first edition by also inviting participants from Ivory Coast, Mali and Niger. Thus, the Récréâtrales became an original and unique concept that foreshadows an African future that could not exist without this confluence of actions and ideas and that is to be built on cooperation and solidarity. Art without sharing ends in sclerosis, and meeting others allows you to challenge yourself and move forward.

Other aspects of this artistic experiment included the emphasis on training and the relationship with 'the population from below'. Each course requires the participants to receive two months of residential training in all aspects of the performing arts, after which they showcase their performances to the public at the festival. Early on, however, the artists realized that only joint productions with theatre companies from the Global North would open venues for a truly international encounter - even if Africa bursts with talent, it still needs to get recognized.

This is a fundamental element of the dream of an African future, a dream that needs to start from below, which is why the Récréâtrales productions stress popular themes (Hagberg et al. 2017; Kibora 2019). Its headquarters are in a popular neighbourhood in west Ouagadougou and, during the festival, the artists decorate the streets and each evening's performance takes place in a family shop where people buy kitchen utensils, firewood and domestic animals. Art is thus taken to the street, as close as possible to ordinary citizens. More than simply being immersed in their community, the artists demonstrate the need to act the future into being together with the other community members. Hence, the Récréâtrales offer a true training and immersion not just for the performing artists but also for the neighbourhood's residents. In the margins

4 Jean-Pierre Guingané, was a Burkinabè writer, university professor and dramatist who created the Theatre of Brotherhood and the Ouagadougou theatre and puppet festival held in Burkina Faso every two years and, for the last ten years in Mali and Niger as well. He died on 23 January 2011 at the age of 66. 


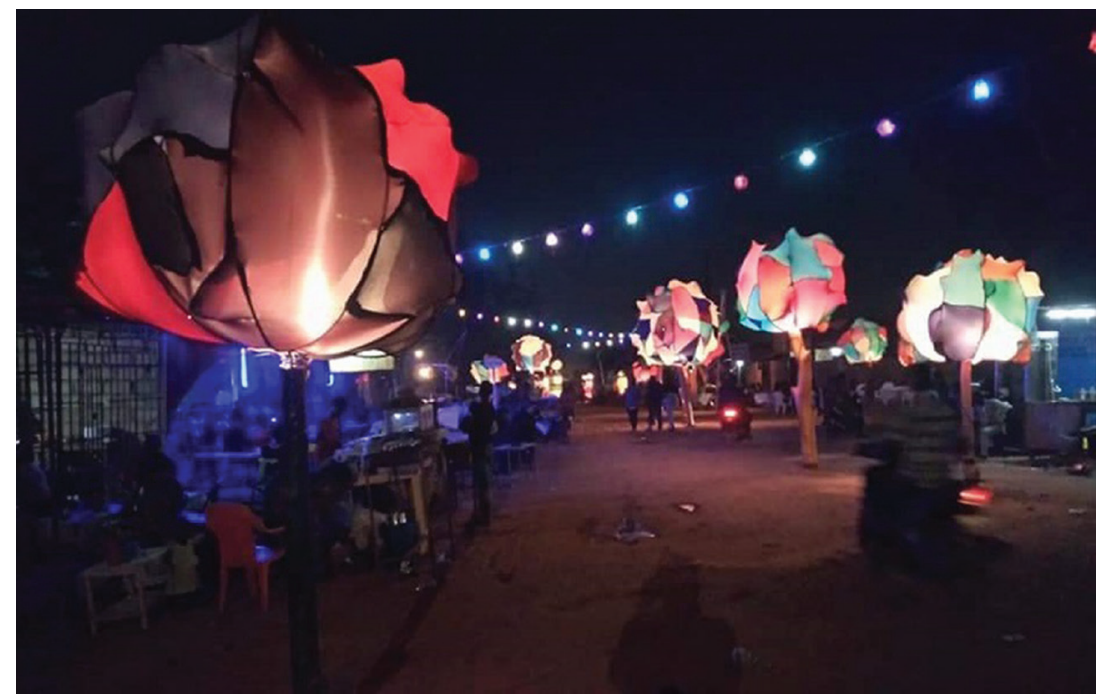

FIGURE 1 The Récréâtrales festival A. MARANÉ

of the manifestation's tenth publication, Aristide Tarnagda, the new director of the Récréâtrales, rightly remarked that

If we want to live with the continent, it is essential to link up with the various countries on the continent, in order to get to know each other and to share the concerns and reflections we all have in common. The Récréâtrales festival is dedicated not only to African artists but also to exploring new horizons, African as well as international ones. We want a contemporary festival, a pan-African festival that opens its doors to the world. 5

It was with this future vision of Africa in mind that the artists managed to invite the president of Burkina Faso, Roch Marc Christian Kaboré, to the neighbourhood on the occasion of its tenth anniversary. The theme was Tresser le Courage (Weave Courage), which the security situation made pertinent.

5 The original French reads: "Si nous voulons coexister avec le continent, il est essentiel de créer des liens entre les différents pays d'Afrique afin de nous connaître, de partager les questionnements que nous avons en commun. Le festival Les Récréâtrales est dédié non seulement à la rencontre des artistes du continent mais aussi à la rencontre de nouveaux horizons, africains comme internationaux. Nous voulons un festival qui soit de son temps, un festival panafricain qui ouvre ses portes au monde" (IFO 2019). 
The sculptor Abou Sidibé, who lives in the Gounghin neighbourhood, has turned his family home into an art gallery and studio in which he works in wood, bronze, or recycled materials: "I live with my sculptures. I think that is an advantage, because it allows me to revisit my creations no matter when, and to add something depending on my inspiration of the moment" (interview with Abou Sidibé, Ouagadougou, 2018).

This Burkinabè artist was born in Ivory Coast, but in 1999 moved to Burkina Faso (from where his parents had come) and, now aged 42, is one of the most eminent Burkinabè artists. He acquired his fine arts degree from Bingerville in Ivory Coast, but not at the expense of his inborn modesty. In 2001, he introduced himself to the art world as being from the capital of the country of 'upright people' 6 when he took part in an exhibition on Les grandes religions révélées (The Great Religions Revealed) at the Olorun Foundation. ${ }^{7}$

Abou Sidibé forms and composes installations. In preparation for the international FAVT exhibition at the National Museum in Ouagadougou (27 September-3 November 2018), the organizing committee asked me to take part in an interesting experiment: based on a series of discussions i had with an artist, she or he would create an artwork depicting an African future. Abou Sidibé was the artist I was allocated. I had seen his works in various exhibitions in Ouagadougou, but this was the first time we met in person. ${ }^{8}$ After our first encounter at the Goethe Institute in the capital we met a further three times in his home studio. Abou Sidibé's called his installation Hèremakono (an allusion to the customary salutation for happiness in the Bambara, Dioula and Malinké languages spoken throughout West Africa). Mindful of the tensions and turbulences of today's world, Hèremakono is a vision of the future inspired by the idea that happiness does not await us - it requires effort, self-confidence and creativity; we need to provoke it, construct it, create it. Abou Sidibé created this assemblage from recycled materials and objects he found around him. With Hèremakono he says that it takes more than words to heal the ailments that stand in the way of a radiant future. Africa can and should succeed by

6 In the national language, "Burkina Faso" means patrie des hommes intègres (homeland of upright men).

7 The Olorun Foundation is an gallery and studio in the Gounghin neighborhood in west Ouagadougou, and directed by a European. For several years it has been working on training and promoting Burkinabè sculptors and designers. Unfortunately, the principal collaborator who commuted between Europe and Burkina Faso to sell the work of his artist collaborators abandoned them. After a few failed attempts these young artists have now been able to set up a new studio and art gallery, the Centre Lukare.

8 Since 2009 I have been on the organizing jury of the Fête international des Arts plastiques de Ouagadougou (Ouagadougou International Festival of Plastic Art). 


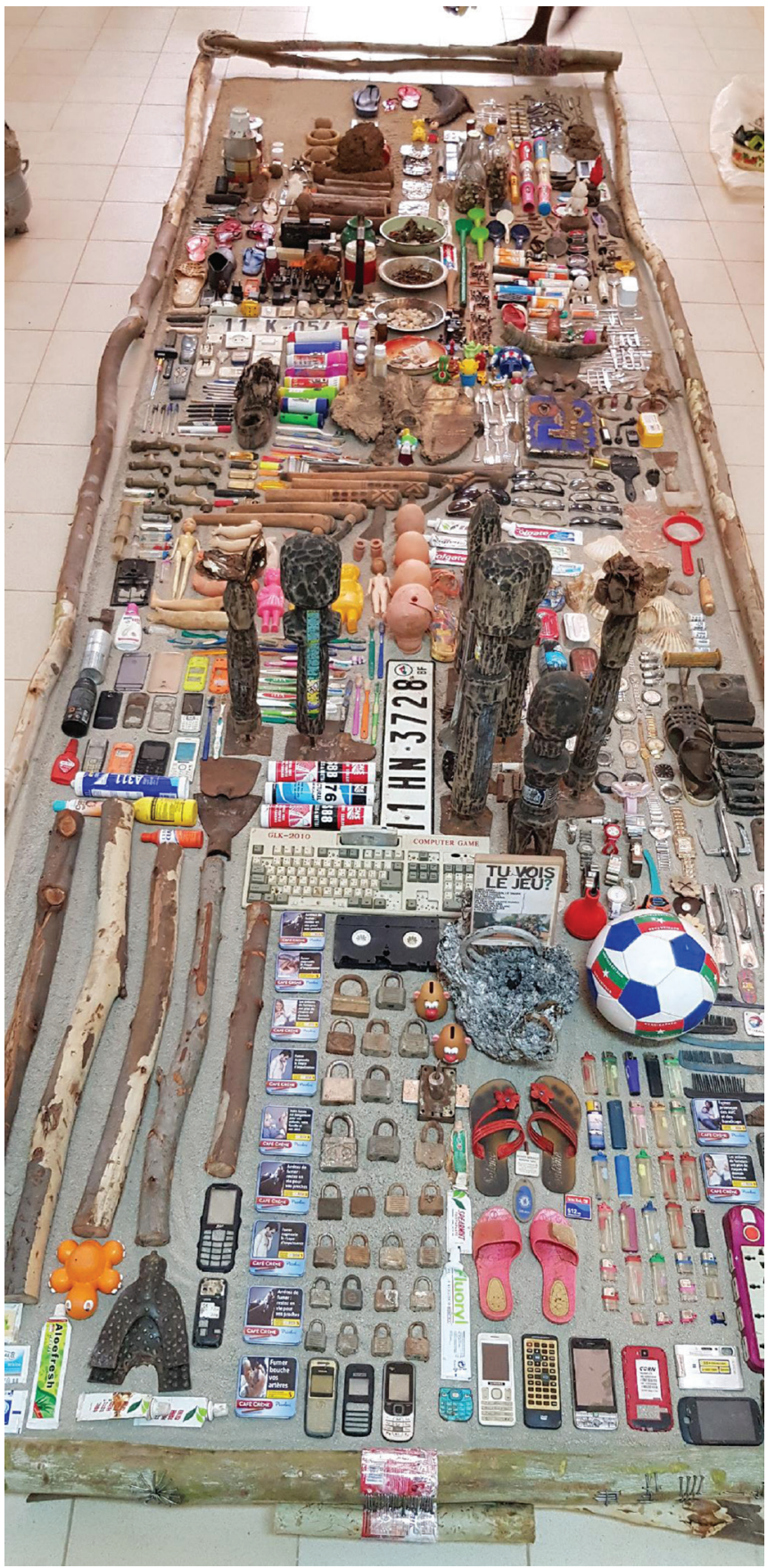

FIGURE 2 Installation by Abou Sidibé. FAVT exhibition at the National Museum in Ouagadougou ABOU SIDIBÉ 
drawing from its cultural and historic treasures, from the creative diversity in today's world.

This understanding of the future is symbolized by a shared vision of the solidarity and inventiveness of Africa's youthful population that knows how to engage with its rich heritage. Eggs will hatch. ${ }^{9}$ Night becomes day. Abou Sidibé's installation claims that before it merges with the larger whole, each object is a message on its own. Thus, he brings across a unique discourse, a strong signal of an Africa that (so far) has made only limited use of its creative potential. This artist's view of the future is a renaissance that takes into account the past of often unequally divided responsibilities. Africa has a rich cultural and historic heritage and must be able to take advantage of the technological advancement of humankind. The artist is in harmony with his world that, consciously or not, whispers these messages in his ear. Bereft of the gift of certainty, through this installation Abou Sidibé invites himself to intellectual debates on development, democracy, and so forth. Without letting himself be influenced by theoretical considerations far removed from his studio, Abou Sidibé shares with us his vision of an endogenous development at the root of a new African identity. This allows him to adopt and adapt things from the outside, without losing sight of the inside. His works breathe lived realities, common concerns and shared dreams in anticipation of happiness. The diversity so central to his art resonates in the way he conceives of the relationship between Africa and the rest of the world. With Hèremakono, Abou Sidibé takes a new start. Unlike those sisters and brothers who fight the adversities of the desert and ocean to reach the other shore, he shows that a model of happiness is possible - it suffices to line up existing forces with the expression of the ideal. To do so, the installation reinvents the spoken word, which speaks with one and the same voice, which heals the evils of the past to inspire (give breath to) a shared vision of renewed solidarity. Thus, in many ways the sculptor converges with the performing artists in their joint vision of the future of the African continent.

Africa, in Hope the Future

In 2014, on the eve of the popular uprising, the eighth Récréâtrales took place in a climate of considerable concern about the future. The theme of the festival, which started in February, was Tenir la main au futur - qu'il ne tremble

9 In one of its corners, Hèremakono holds a few chicken eggs. 
pas, qu'il sourit (Hold hands in the future - let it not tremble, let it smile). The programme included a work choreographed by Serge Aimé Coulibaly called Nuit blanche à Ouagadougou (White Night in Ouagadougou), which premiered on 30 October and, as its title suggests, it prefigured the October uprisings, not least because the rapper Smockey was playing the leading role. Smockey was also a co-founder of the Balai Citoyen (citizens' broom) movement, and with other musicians like reggae artist Sams'K Le Jah, was at the forefront of the popular movement that ousted Compaoré the very next day.

Artists have a particularity in common: they are quick to distil from the collective unconsciousness the circadian phenomena and objects trivialized by the daily grind of everyday life. The quotidian, the banal is hence endowed with a sense beyond the common, and this only reinforces its expressivity. Looking at the performing artists of the Récréâtrales or at the Hèremakono sculpture - they all share a view in common, which leads to the following fundamental conclusions.

First, any African future needs to be built on a solid cultural and historic foundation. Local knowledge and know-how are underutilized and insufficiently understood by researchers and politicians (Diop 1954; Kibora 2010; Ki-Zerbo 2004). It is only there that one can find the necessary resources for a genuine vision, one that is not copied from others.

Second, training is essential for developing and perfecting different forms of knowledge, even if they are localized. In this, recognizing the diversity of knowledge and ways of knowing is a guarantee for success, but it needs work.

Third, for this vision to be commonly shared, solidarity between African countries is vital. Despite state organized divisions, the solidarity the Récréâtrales have been bringing for the past twenty or so years, has still not been properly realized. At the launch of the 2020 festival, its new president Odile Sankara, younger sister of President Thomas Sankara, said, "We cannot do this job and ignore what is going on around us, so standing up is also a way of continuing to dream, to believe in life" (Revelyn 2020, author's translation).

Fourth, the future of Africa resonates with cultural diversity and openness to the world. This dimension clearly permeates the two forms of art discussed above. While it is unnecessary to copy the West, to further one's own goals it is important to tap into progress made elsewhere in the world.

Despite the turbulences we experience nowadays, artists and the vast majority of the young population still seem to share a certain optimism in their contemporary understandings of the world and vision for the future. As Claude Frochaux (1996: 330, my translation) eloquently expressed it, "This is not wrong: artists are ahead of the crowd. But one understands the phenomenon 
better if one starts from the crowd than when one starts from the artist. It is not the artist who is ahead. It is the crowd that is behind."

Africa needs to complete its decolonization and abandon the balls and chains that drag it down - and there are many. Yet, the most important one is the desire to adhere to a technical vision of human development without having sufficiently explored local cultural resources. It is in this sense that artists like Abou Sidibé, or the performing artists in the Récréâtrales, emphasize the need to reinvent development by brazenly promoting an endogenous take on socio-economic progress. This reinvention of 'development' by the artist is key to the relationship between Africa and the Global North. Any future history of democracy and development, the two main gauges by which Africa is measured and judged, should incorporate the continent's enormous internal cultural potential, which has been poorly explored and hardly exploited. To do so, culture must be at the centre of each social initiative and every political decision. This is why artists are the torchbearers of this message of hope and why it is from them that an African future will spring.

\section{References}

Appadurai, A. 2013. The future as cultural fact: Essays on the global condition. London: Verso.

Chouli, L. 2015. "The popular uprising in Burkina Faso and the Transition." Review of African Political Economy, 42, 144: 325-333.

Diop, C. A. 1954. Nations nègres et culture. Paris: Éditions Africaines.

Diop, C. A. 1996. Towards the African Renaissance: Essays in African culture and development, 1946-1960. Trenton, NJ: Red Sea Press.

Do-Nascimento J. (Ed.). 2008. La renaissance africaine comme alternative au développement: Les termes du choix politique en Afrique. Paris: L'Harmattan.

Frère, M.-S. and P. Englebert. 2015. "Briefing: Burkina Faso-the fall of Blaise Compaoré." African Affairs, 114, 455: 295-307.

Frochaux, C. 1996. L'Homme seul. Lausanne: Éditions l'Âge d'Homme.

Hagberg, S. 2015. "Thousands of new Sankaras': Resistance and struggle in Burkina Faso." Africa Spectrum, 50, 3:109-121.

Hagberg S. 2017. "Introduction." In Nothing will be as before!': Anthropological perspectives on political practice and democratic culture in 'a new Burkina Faso', edited by S. Hagberg, L. Kibora, B. Sidi, G. Siaka and K. Adjara, 1-18. Uppsala: Uppsala University Press.

Hagberg, S., L. Kibora, B. Sidi, G. Siaka and K. Adjara. 2017.'Nothing will be as before!': Anthropological perspectives on political practice and democratic culture in 'a new Burkina Faso'. Uppsala: Uppsala University Press. 
Hagberg, S., L. Kibora, B. Sidi, G. Siaka and K. Adjara. 2019. Security from the bottom. Perception and participation in security challenges in Burkina Faso. Uppsala: Uppsala University Press.

IFO 2019. “Aristide Tarnagda." Interview. Institut Français. https://www.institutfrancais. com/fr/rencontre/aristide-tarnagda [29 January 2020].

Jaffré, B. 1997. Biography of Thomas Sankara. The homeland or death. Paris: L'Harmattan. Kibora, L. O. 2010. "Pratiques et développement au Burkina Faso: Une contribution de l'anthropologie [Practices and development in Burkina Faso: A contribution from anthropology].” Études sahéliennes, 4: 57-66.

Kibora, L. O. 2019. "Réactions populaires aux attaques terroristes de janvier 2016 à Ouagadougou [Popular reactions to the January 2016 terrorist attacks in Ouagadougou]." Mande Studies, 21: 55-69.

Kibora, L. and F. Bationo. 2010. "Death alone is the limit. Etienne Minoungou, Ildevert Méda and the Récréâtrales Festival." In Theatre in sub-Saharan Africa, edited by R. G. Hemke, 51-54. Berlin: Théater der Zeit.

Kibora, L., T. Mamadou and B. Niagalé (Eds). 2017. Towards reforming of the Burkinabè security system? Paris: FRs. https://www.frstrategie.org/en/programs/observatoiredu-monde-arabo-musulman-et-du-sahel/towards-reforming-burkinabe-securitysystem-2017 [5/6/2020].

Kibora, L., P. Kouraogo and K. Amado. 2018. “The self-defense groups' Koglweogo in Burkina Faso: What future?" African Research:Annals of the University of Letters and Human Sciences of Bamako, 20: 303-316.

Ki-Zerbo, J. 2004. À quand l'Afrique: Entretien avec René Holenstein [When is Africa? Interview with Réné Holenstein]. La Tour d'Aigues: L'Aube.

Martens, L. and H. Meesters. 1989. Sankara, Compaoré and the Burkinabè revolution. Anvers: EPO.

Mbembé, A. 2010. Leaving the big night. Essay on decolonized Africa. Paris: La Découverte.

Mbembe, A. 2020. Out of the dark night. Essays on Decolonization. New York: Colombia University Press.

Revelyn 2020. "Recréâtrales 2020: 'Nous dresser comme un seul homme face au barbarisme' (Aristide Tarnagda)." Burkina 24. https://www.burkina24.com/2020/o3/o1/ recreatrales-202O-nous-dresser-comme-un-seul-homme-face-au-barbarisme-aristide-tarnagda/ [27/7/2020].

Sarr, F. 2016. Afrotopia. Paris: Phillipe Rey Editions.

Sennen, A. 1989. His name was Sankara. Paris: Japress.

Somé, V. D. 1990. Thomas Sankara: L'espoir assassiné [hope assassinated]. Paris: L'Harmattan. 